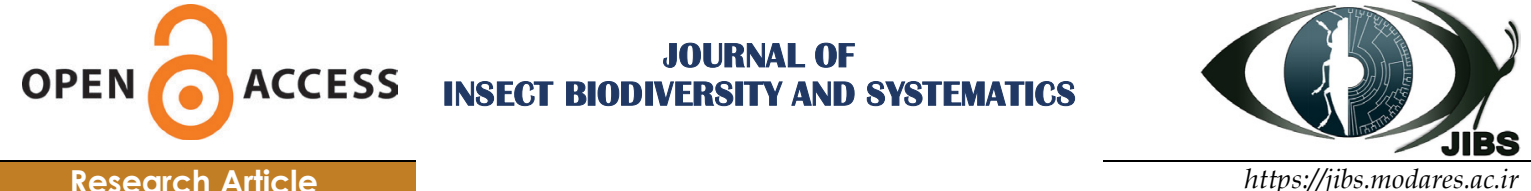

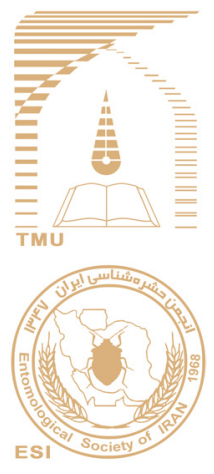

\section{First report of the occurrence of the genus Pantolyta Foerster, 1856 (Hymenoptera: Diapriidae) from Iran}

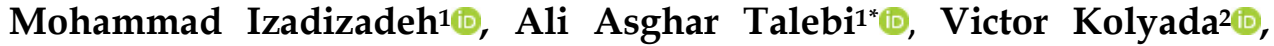 \\ Samira Farahani ${ }^{3}$, Farzaneh Kazerani ${ }^{3}$ [D $\&$ Ali Ameri ${ }^{4}$ (i) \\ 1 Department of Entomology, Faculty of Agriculture, Tarbiat Modares University, Tehran, Iran. \\ mohammad.izadizadeh@modares.ac.ir; talebia@modares.ac.ir \\ 2 Paleontological Institute, Russian Academy of Sciences, 123 Profsoyuznaya Str., Moscow, 117997, Russia. \\ proctos@gmail.com \\ 3 Research Institute of Forests and Rangelands, Agricultural Research Education and Extension Organization, \\ Tehran,Iran.s.farahani@rifr-ac.ir; farzane.kazerani@gmail.com \\ 4 Insect Taxonomy Research Department, Iranian Research Institute of Plant Protection, Agricultural Research, \\ Tehran,Iran.ameri@iripp.ir
}

A BSTRACT. During our studies on the family Diapriidae, two species of the genus Pantolyta Foerster, 1856 were collected and identified for the first time from Iran: Pantolyta pallida Kieffer, 1908 and Pantolyta nixoni Macek, 1993. A key to the Iranian species of the genus Pantolyta and diagnostic characters for both

Received: newly recorded species are provided along with illustrations. In addition, distribution map of the two species in the Palaearctic region is presented.

Accepted:

20 October, 2020

Published:

24 October, 2020

Subject Editor:

Vasilisa Chemyreva

Key words: Pantolytini, Pantolyta pallida, Pantolyta nixoni, key, description, distribution

Citation: Izadizadeh, M., Talebi, A.A., Kolyada, V., Farahani, S., Kazerani, F. \& Ameri, A. (2021) First report of the occurrence of the genus Pantolyta Foerster, 1856 (Hymenoptera: Diapriidae) from Iran. Journal of Insect Biodiversity and Systematics, 7 (1), 51-58.

\section{Introduction}

Diapriidae is a large family of Diaprioidea Haliday, 1833 with more than 2100 species and worldwide distribution. This family includes three subfamilies: Ambositrinae Masner, 1961, Belytinae Foerster, 1856 and Diapriinae Haliday, 1833 (Sharkey et al., 2012). The subfamily Belytinae with more than 50 genera and about 700 species is cosmopolite and prefer wet and shady habitats such as forests, marshlands, peatbogs and wet meadows (Quadros \& Brandao, 2017). Biology and host association of the subfamily Belytinae is poorly known. As far as is known, species of the subfamily Belytinae are larval and pupal endoparasitoids of Mycetophilidae and Sciaridae (Diptera) (Nixon, 1957; Huggert, 1979; Yoder, 2007) with exclusion of some Synacra species on Musca domestica (Muscidae) (Floate et al., 1999), but according to Hellqvist (1994), larval instars are the preferred host stages for parasitism by members of Belytinae. In addition, some species have been reported in association with ant

Corresponding author: Ali Asghar Talebi, E-mail: talebia@modares.ac.ir

Copyright (C) 2021, Izadizadeh et al. This is an open access article distributed under the terms of the Creative Commons Attribution License (CC BY 4.0), which permits unrestricted use, distribution, and reproduction in any medium, provided the original author and source are credited. 
nests (Nixon, 1957; Huggert, 1979). Members of this subfamily are classified in three tribes: Belytini Foerster, 1856, Oxylabini Kozlov, 1978 and Pantolytini Hellen, 1964 (Kozlov, 1978). In the next studies, Macek (1989) and Chemyreva (2019) reexamined the subfamily Belytinae and reclassified this subfamily into three tribes (e.g., Belytini Foerster, 1856, Cinetini Macek, 1989 and Pantolytini Hellen, 1964). The tribe Pantolytini includes 11 genera in Palaearctic region: Acanopsilus Kieffer, 1908, Acanosema Kieffer, 1908, Acropiesta Foerster, 1856, Anommatium Foerster, 1856, Cardiopsilus Kieffer, 1908, Opazon Haliday, 1857, Pantolyta Foerster, 1856, Polypeza Foerster, 1856, Psilomma Foerster, 1856, Psilommacra Macek, 1990, and Synacra Foerster, 1856 (Macek, 1989, 1990).

The genus Pantolyta Foerster, 1856 includes eight species in the world (Chemyreva \& Kolyada, 2019). All known species are distributed in Palaearctic region (Macek, 1993; Chemyreva \& Kolyada, 2019). The first revision of this genus was prepared by Macek (1993), who listed seven species in Europe and provided identification key to European species. Chemyreva \& Kolyada (2019) described a new species from Russia and Japan and provided identification key to Palaearctic species. Prior to this study, there were no records of the subfamily Belytinae from Iran. Recently, six genera and eight species from subfamily Diapriinae including Aneuropria Kieffer, 1905 (1 species), Coptera Say, 1836 (2 species), Diapria Latreille, 1796 (1 species), Entomacis foerster, 1856 (1 species), Spilomicrus Westwood, 1832 (1 species) and Trichopria Ashmead 1893 (2 species) are reported from Iran (Izadizadeh et al., 2020). This research is a part of our ongoing research on the superfamily Diaprioidea Haliday, 1833 in Iran.

\section{Material and methods}

Material for this study was collected from northern Iran using Malaise traps. The specimens were extracted from the traps and sorted monthly, transferred to $70 \%$ ethylalcohol, and then stored in a freezer for further studies. For the preparation of samples, specimen placed on a piece of absorbing paper for drying. The dried specimens were card-mounted and labelled. Illustrations were done using an Olympus AX70 microscope and Olympus SZX9 stereomicroscope equipped with a BMZ-04-DZ digital imaging system (Behin Pajouhesh Co., Iran). A series of four or five captured images were merged into a single in-focus image using the image-stacking software Combine ZP1.0. Morphological terminology follows Nixon (1957), Masner \& García (2002), Quadros \& Brandao (2017) and Chemyreva \& Kolyada (2019). Map of the distribution of species is created using SimpleMappr (Shorthouse, 2010). Specimens are deposited in the insect collection of the Department of Entomology, Tarbiat Modares University, Tehran (TMUC) and the Research Institute of Forests and Rangelands, Tehran (RIFR).

The following abbreviations are used: A1-A15 = Antennomeres: segments of the antenna; they are numbered from the scape (A1) to the apical segment (A15), OOL = ocular ocellar line: the shortest distance between the posterior ocellus and the eye, $\mathrm{POL}=$ posterior ocellar line: the shortest distance between the posterior ocelli.

\section{Results}

Two species of the genus Pantolyta were collected and identified, Pantolyta pallida Kieffer, 1908 and Pantolyta nixoni Macek, 1993. This is the first record of the genus Pantolyta for the fauna of Iran. 
Family Diapriidae Haliday, 1833

Subfamily Belytinae Foerster 1856

Tribe Pantolytini Hellen, 1964

Genus Pantolyta Foerster, 1856

Type Species: Pantolyta atrata Foerster, 1861

Morphological characters: Body length 1.5-2.5 mm; head subglobose with hypognathous mouthparts; clypeus moderately convex; eyes pubescent; male antenna 14 segmented with A3 modified at base, female antenna 15 segmented, mesosoma wider than high; epomia present; mesonotum convex, notauli well developed, scutellum slightly convex, with large subrectangular fovea anteriorly; metanotum with distinct dorsellum; propodeum a little transverse with simple median and lateral keels; fore wing well developed, (some specimens of Pantolyta atrata Foerster, 1861, P. pallida Kieffer, 1908 and P. stylata Kieffer, 1908 are brachypterous), costal, subcostal veins tubular, basal vein sclerotized to nebulous, radial cell developed or obliterate, marginal vein longer than parastigma; petiole short, not more than 1.5 times as long as wide, with coarse longitudinal rugosity.

Key to species of the genus Pantolyta in Iran

- Radial cell open; axillar depression with verriculate tubercle. ............. Pantolyta pallida

- Radial cell closed; axillar depression without verriculate tubercle. Pantolyta nixoni

\section{Pantolyta nixoni Macek, 1993}

Material examined: Iran: Mazandaran, Kheyrud Kenar (36³4'36.23" N, 51³4'37.94" E, 722 m a.s.1), 26.VI.2018, 1へ( (RIFR), Leg.: F. Kazerani.

Morphological characters: Male (Fig. 1A). Body length $1.7 \mathrm{~mm}$; colour brown; fore wing length $1.6 \mathrm{~mm}$; head not nasiform; antennal shelf slightly prominent (Fig. 1B), A1 longer than half of head width, with apical flanges, A3-A14 with pubescence nearly as long as width of antennomeres (Fig. 1D); POL 0.6 times as long as OOL (Fig. 1C); pronotal collar and pronotal shoulders smooth, epomia obsolete; axillar depression without verriculate tubercle (Fig. 1C); radial cell 0.52 times as long as marginal vein (Fig. 1E); medial propodeal keel narrowly forked, dorsal area of propodeum with sparse setae; petiole 1.35 times as long as wide in dorsal view, with four longitudinal carinae (Fig. 1C).

Distribution in Iran: Mazandaran province (current study). New record for Iran.

General distribution: (Fig. 3) Germany, Sweden, Czech Republic, Hungary, Poland, Russia, Azerbaijan (Macek, 1993; Chemyreva \& Kolyada, 2019).

\section{Pantolyta pallida Kieffer, 1908}

Material examined: Iran: Gilan province, Astara, Lavandvil forest $\left(38^{\circ} 18^{\prime} 19^{\prime \prime} \mathrm{N}, 48^{\circ} 42^{\prime} 57^{\prime \prime} \mathrm{E}\right.$, 873m a.s.1.), 06.VI.2017, 1우 (TMUC), Leg.: S. Farahani.

Morphological characters: Female (Fig. 2A). Body length $2.8 \mathrm{~mm}$ (with ovipositor sheath); fore wing length $2.1 \mathrm{~mm}$; head not nasiform (Fig. 2C), in dorsal view wider than mesosoma; POL 0.6 times as long as OOL; antennal shelf weakly prominent, A1 with apical flanges, antennae slender (Fig. 2D); genae in frontal view moderately convex (Fig. 2B); pronotal collar and pronotal shoulders smooth; axillar depression with verriculate tubercle (Fig. 2E); 
radial cell open (Fig. 2F); marginal vein 1.6 times as long as parastigma; dorsal area of propodeum bare (Fig. 2E); petiole 1.35 times as long as wide in dorsal view.

Distribution in Iran: Gilan province (current study). New record for Iran.

General distribution: (Fig. 3) England, Germany, Sweden, Czech Republic, Hungary, Poland, Ukraine, Russia, Georgia, Armenia, Kazakhstan, Turkmenistan, Tajikistan, Mongolia, North Korea, South Korea, Japan (Macek, 1993; Chemyreva \& Kolyada, 2019).
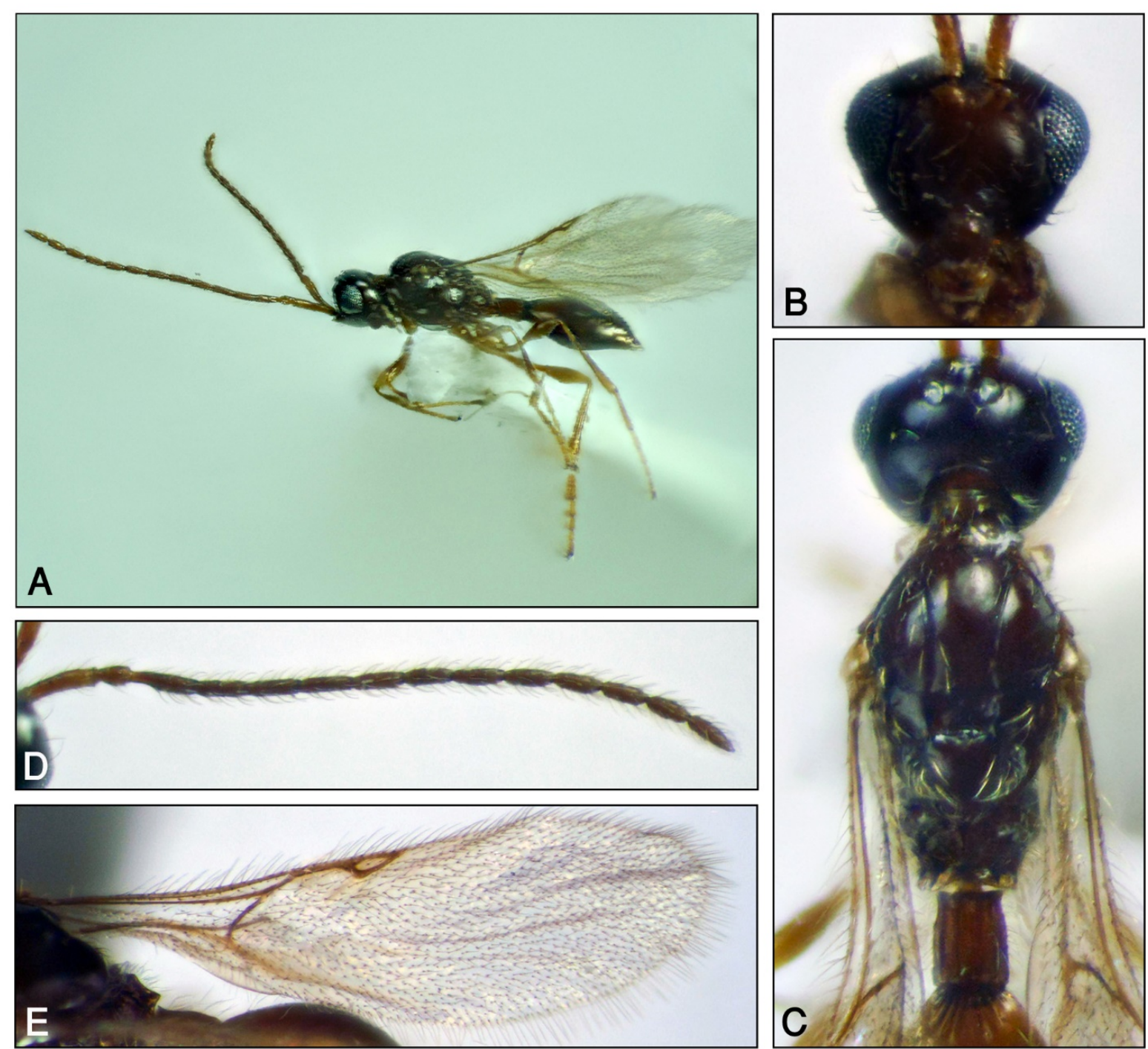

Figure 1A-E. Pantolyta nixoni Macek, 1993, male; A. general habitus, lateral view; B. head, frontal view; C. head and mesosoma, dorsal view; D. antenna; E. fore wing venation. 

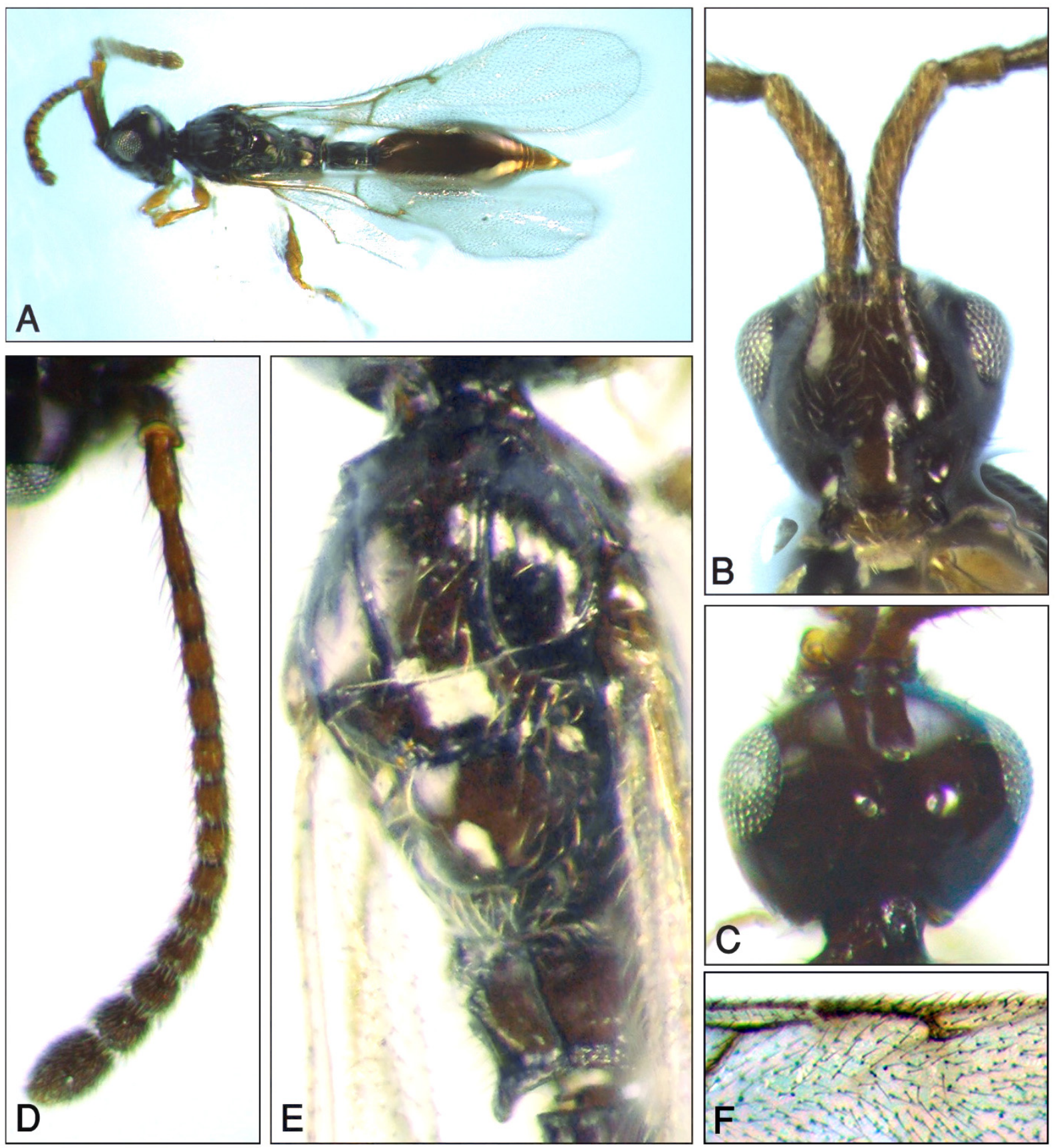

Figure 2A-F. Pantolyta pallida Kieffer, 1908, female; A. general habitus, dorsal view; B. head, frontal view; C. head, dorsal view; D. antenna; E. mesosoma, dorsal view; F. fore wing venation.

\section{Discussion}

The genus Pantolyta and two species P. nixoni and P. pallida are reported from Iran for the first time based on two specimens that have been collected from Gilan and Mazandaran provinces in northern Iran. Specimens were collected using Malaise traps, therefore, the biology of the recorded species is unknown. Members of the genus Pantolyta are rarely collected in this study using Malaise traps, but at least some of the Palaearctic species of this 
genus are very common (Macek, 1993; Chemyreva \& Kolyada, 2019). In this study, we provided the morphological characters based on the two Iranian specimens, and it should be noted that some features may be variable in the population of each species. The Pantolyta species prefer the humid and shady forest habitats (Macek, 1993). North Central of Iran, adjacent to Caspian Sea, includes Golestan, Mazandaran and Gilan provinces with high to semi humid climate and for the diverse forests is convenient region for Pantolyta species. Biology and hosts of the Pantolyta species are unknown (Macek, 1993; Chemyreva \& Kolyada, 2019). The number of species recorded in Iran is still low (two species) in comparison to the known Palaearctic fauna (eight species). The number of species of Pantolyta in the adjacent countries of Iran is recorded as: seven species in Russia (Chemyreva \& Kolyada, 2019), one species in Armenia, Azerbaijan, Turkmenistan and Tajikistan (Chemyreva \& Kolyada, 2019), and none yet recorded from Afghanistan and Turkey. As many areas of Iran have not yet been explored, it is expected that the species number of the genus Pantolyta in Iran will be substantially increased in future.

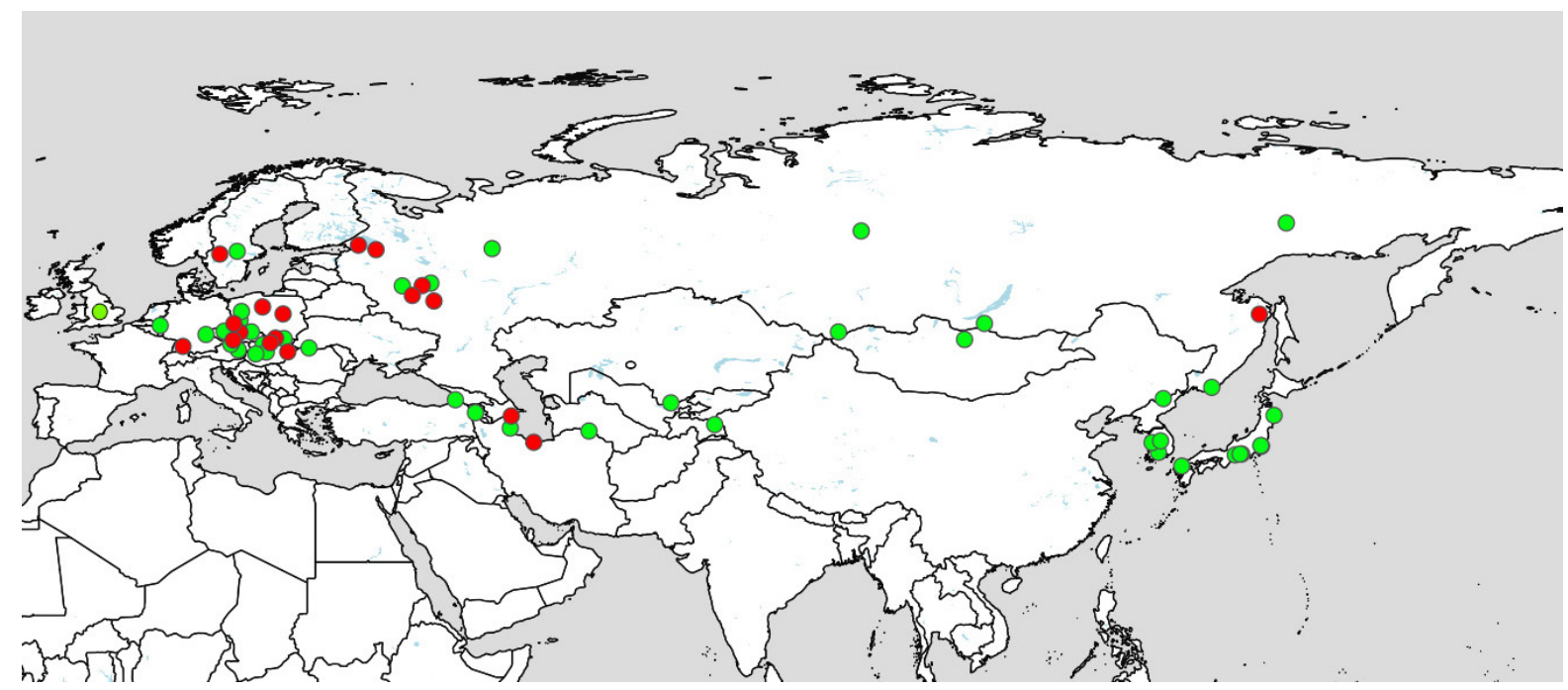

Figure 3. Distribution map of Pantolyta nixoni Macek, 1993 (red) and Pantolyta pallida Kieffer, 1908 (green) in Palaearctic region.

\section{Acknowledgments}

We would like to thank the Department of Entomology, Tarbiat Modares University and Research Institute of Forests and Rangelands for providing financial support. We cordially thank Dr. Jan Macek (National Museum, Czech Republic) and Dr. Vasilisa G. Chemyreva (Zoological Institute, Russian Academy of Sciences, Russia) for their critical review and constructive comments, which significantly helped the improvement of the manuscript.

\section{Conflict of Interests}

The authors declare that there is no conflict of interest regarding the publication of this paper.

\section{ORCID}

Mohammad Izadizadeh: http:/ / orcid.org/0000-0002-8724-0132

Ali Asghar Talebi: https:/ / orcid.org/0000-0001-5749-6391

Victor Kolyada: https:/ / orcid.org/0000-0001-5459-0796 
Samira Farahani: https:/ / orcid.org/0000-0002-6897-0631

Farzaneh Kazerani: https:// orcid.org/0000-0003-1968-3350

Ali Ameri: https:/ / orcid.org/0000-0003-2372-8494

\section{References}

Chemyreva, V.G. \& Kolyada, V.A. (2019) Review of the Pantolyta genus (Hymenoptera: Diapriidae: Pantolytini) from Russia, with description of a new species. Zoosystematica Rossica, 28 (1), 163176. https://doi.org/10.31610/zsr/2019.28.1.163

Chemyreva, V.G. (2019) Family Diapriidae. In: Belokobylskij, S.A., Samartsev, K.G. \& Il'inskaya A.S. (eds.) Annotated catalogue of the Hymenoptera of Russia. Volume II. Apocrita: Parasitica. Proceedings of the Zoological Institute Russian Academy of Sciences. Supplement 8. Zoological Institute RAS, St Petersburg, pp. 35-40.

Floate, K.D., Khan, B.G. \& Gibson, G. (1999) Hymenopterous parasitoids of filth fly (Diptera: Muscidae) pupae in cattle feedlots. The Canadian Entomologist, 131, 347-362. https://doi.org/10.4039/Ent131347-3

Hellqvist, S. (1994) Biology of Synacra sp. (Hym., Diapriidae), a parasitoid of Bradysia paupera (Dipt., Sciaridae) in Swedish greenhouses. Journal of Applied Entomology, 117 (1-5), 491-497. https://doi.org/10.1111/j.1439-0418.1994.tb00766.x

Huggert, L. (1979) Cryptoserphus and Belytinae wasps (Hymenoptera, Proctotrupoidea) parasitizing fungus- and soil-inhabiting Diptera. Notulae Entomologicae, 59, 139-144.

Izadizadeh, M., Talebi, A. A., Kolyada, V., Farahani, S. \& Ameri, A. (2020) First record of two genera and species of Diapriinae (Hymenoptera: Diapriidae) from Iran. Journal of Crop Protection, 9 (2), 319-325.

Kozlov, M. A. (1978) Fam. Proctotrupidae. In: Medvedev, G.S. (Ed.) A key to the insects of the European Part of the USSR. Opredelitel' nasekomykh evropeiskoi chasti SSSR. Nauka Publishers, Leningrad. pp. 538-664 (in Russian).

Macek, J. (1989) Studies on the Diapriidae (Hymenoptera, Proctotrupoidea). Part 1. Taxonomic remarks on the subfamily Belytinae with particular reference to the Pantolytini. Annales Zoologici, 42, 353-362.

Macek, J. (1990) Revision of European Psilommina (Hymenoptera, Diapriidae) 1. Psilomma and Acanosema complex. Acta Entomologica Musei Nationalis Pragae, 43, 335-360.

Macek, J. (1993) Revision of European Pantolyta Föester (Hymenoptera, Diapriidae). Folia Heyrovskiana, 1 (5), 41-51.

Masner, L. \& García J.L. (2002) The genera of Diapriinae (Hymenoptera: Diapriidae) in the New World. Bulletin of the American Museum of Natural History, 268, 1-138. https://doi.org/10.1206/0003-0090(2002)268\%3C0001:TGODHD\%3E2.0.CO;2

Nixon, G.E.J. (1957) Hymenoptera, Proctotrupoidea, Diapriidae, subfamily Belytinae. Handbooks for the Identification of British insects, 8 (3dii), 1-107.

Quadros, A.L. \& Brandão, C.R.F. (2017) Genera of Belytinae (Hymenoptera: Diapriidae) recorded in the Atlantic Dense Ombrophilous Forest from Paraíba to Santa Catarina, Brazil. Papéis Avulsos de Zoologia, 57 (6), 57-91. https://doi.org/ 10.11606/0031-1049.2017.57.06

Sharkey, M.J., Vilhelmsen, L., Heraty, J., Liljeblad, J., Dowling, A.P.G., Schulmeister, S., Murray, D., Deans, A.R., Ronquist, F., Krogmann, L. \& Wheeler, W.C. (2012) Phylogenetic relationships among superfamilies of Hymenoptera. Cladistics, 28, 80-112. https://doi.org/10.1111/j.1096-0031.2011.00366.x

Shorthouse, D.P. (2010) SimpleMappr, an online tool to produce publication-quality point maps. Available from: http://www.simplemappr.net/ [Accessed 26th July 2020].

Yoder, M.J. (2007) Advances in diapriid (Hymenoptera: Diapriidae) systematics, with contributions to cybertaxonomy and the analysis of rRNA sequence data. (Unpublished PhD Dissertation), Texas A \& M University. 185 pp. 
اولين كزارش از حضور جنس Hymenoptera: Diapriidae) Pantolyta Foerster, 1856 در ايران محمد ايزدى زاده'، على اصغر طالبى ".، ويكتور كوليادا'، سميرا فراهانى"، فرزانه كازرانى "و على عامرى

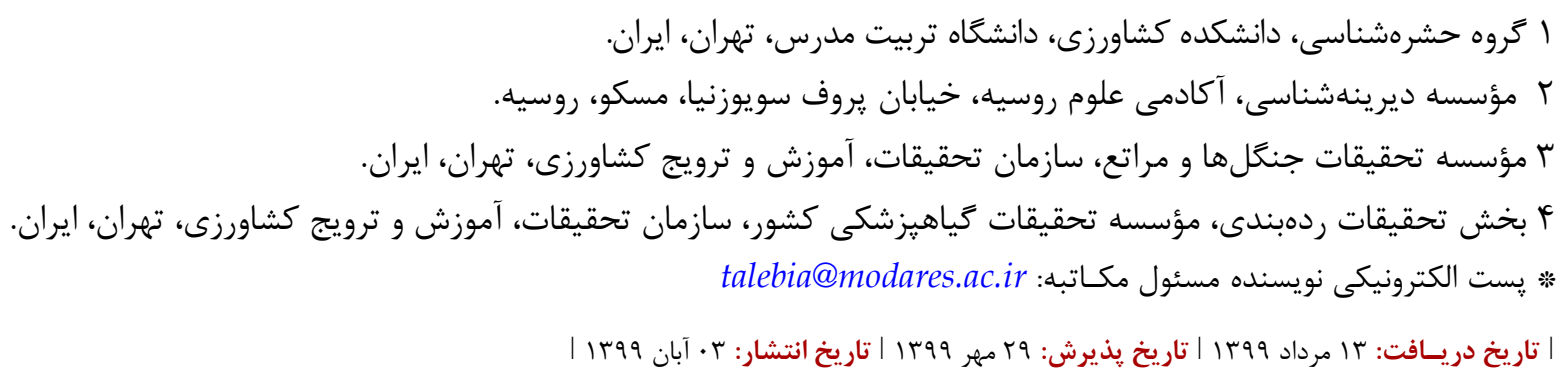
קكيـده: طى مطالعهُ خانوادة Diapriidae در ايران، دو گَونه از جنس Pantolyta

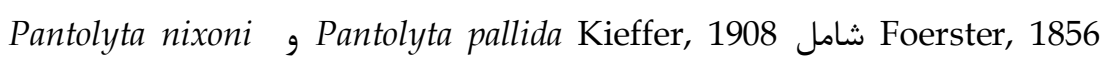
براى اولين بار از ايران جمعآورى و شناسايى شد. كليد شناسايى

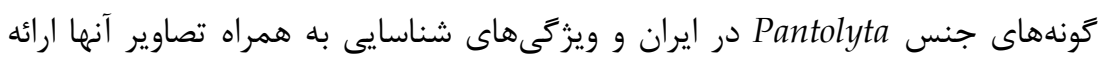

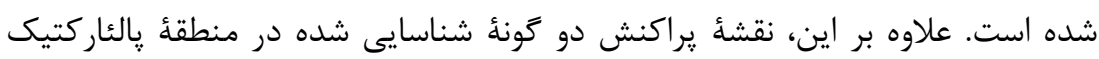
ارائه شده است.

وازگَـان كليدى: Pantolytini، Pantolyta pallida، شناسايى، توصيف، يراكنش 